\title{
ACADEMIC LAWYERS AND LEGAL \\ PRACTICE IN ENGLAND: TOWARDS A \\ NEW RELATIONSHIP?
}

\author{
MARTIN PARTINGTON*
}

\section{INTRODUCTION}

The theme of this conference - legal academia - raises for discussion and analysis basic questions about the current state and status of the legal academy. It implies historical questions: how have we arrived at the position we are in today? It implies predictive questions: how are we likely to develop in the years ahead? How should we be developing? It also implies comparative questions: is what we do here similar/dissimilar to what goes on in other common law countries? In the civil war jurisdictions? In the (former?) Eastern Bloc countries? A complete and comprehensive analysis of all these issues would require a substantial research agenda.

Despite the potentially vast scope of the enterprise sketched out above, this paper addresses a narrower set of issues that revolve around the questions: what should the status of the legal academic be? What should the relationship be between the legal academic and the legal practitioner? ${ }^{1}$ In what follows there will inevitably be a rather narrow focus on the position in England. ${ }^{2}$ Nevertheless, the conference agenda does suggest that some consideration of the matters discussed here form at least part of the agenda in Australia and New Zealand as well. It must also be acknowledged that much of the inspiration for developments occurring in England derive from experience and expertise developed in Australia and New Zealand. The Paper falls into two main parts: Part One looks at 
developments at Higher Education policy in Britain and the responses of law schools to them; Part Two explores the changing relationship between legal academics and legal practitioners in England. Finally some conclusions are drawn.

\section{PART ONE — POLICY ON HIGHER EDUCATION IN BRITAIN}

Before proceeding further, however, it is important to be reminded of the broader public policy context within which Higher Education is currently placed. In Britain, the basic structure of higher education as it now exists was effectively prescribed in 1963 by the publication of the Robbins Report. ${ }^{3}$ This led to a substantial expansion of the university sector of higher education in the late 1960s and also to the emergence of the polytechnic sector, from former Colleges of Advanced Technology, who were given the ability to offer degree level courses, accredited by a central body, the Council for National Academic Awards. The "binary line”, with the universities on the one side and the polytechnics on the other, was widely regarded as creating a two-tier system of higher education: the Universities still attracted the resources to fund research as well as teaching; the Polytechnics were funded less generously, with the emphasis there being more on teaching and less on research.

In the late 1960s and early 1970s resources were available from the public purse to allow both sectors to develop. However from the mid-1970s onwards, the fiscal implications of the policy of expansion became increasingly clear, and financial matters became increasingly sharply drawn. No longer was expansion effectively driven by the institutions asking for more resources; the Treasury became more and more reluctant to part with money. ${ }^{4}$

When the Conservative Government came to power in 1981, the attack on the financial position of the Universities, in particular, became more overt. Initially, reductions in student numbers going to university were officially forecast, which were used to justify sharp cuts in actual levels of expenditure. ${ }^{5}$ Naturally the Universities sought to challenge the basis for these policies. Alternative predictive models for student numbers were advanced which showed an increase in demand for places, rather than a 
decline. Eventually this led to the Government amending its policy. It accepted the universities' case for increased student numbers. Indeed it became committed to increasing the "participation rate" - the numbers of school-leavers able to enter the higher education system in general. ${ }^{6}$

The Government did not, however, fundamentally change its approach to funding. Indeed it became ever more determined to drive down, so far as it could, the "unit of resource". This was done by both allowing unrealistically low levels of inflation when increasing the level of government funding plus the imposition of what were (and are) euphemistically described as "efficiency gains”. In this, the Universities - perceived as expensive - were successfully played off against the Polytechnics - perceived as cheaper. In addition to policies relating to resources, at least five further policies were being developed by Government:

First, was that "industry" - broadly defined — should pay more for the work done in the Universities and Polytechnics, from which it derived benefits. Most of this discussion focused on the financial support for applied research; but the argument also applied to advanced educational and training programmes as well. Universities and Polytechnics, used to charging rather "notional" levels of fees, were encouraged to become much more commercial and recover the full costs of providing services. ${ }^{7}$

Secondly, Universities should become more "enterprising”, not just in the sense that they should be more commercial in their marketing, but also in terms of preparing their students for work in the "enterprise" culture. A consistent theme has been the encouragement of Universities to at least be aware of and respond to vocational needs. ${ }^{8}$

A third, was that University management structures should be overhauled. ${ }^{9}$ There was to be greater devolution of financial management into departments to encourage both greater freedom in decision-taking and greater accountability for decisions taken. In this way it was intended that there would be better use of the resources that were provided for the Universities. At the same time, Universities were asked to establish planning committees that comprised at least an element of "lay" (external) membership. This move was designed to encourage the university sector to be more responsive to outside (market) pressures. 
A fourth, more recent policy has been that Universities and Polytechnics should become much more flexible in their pay structure. Traditionally accepted mechanisms, whereby salaries were negotiated nationally and staff were paid (broadly) the same in each institution, were to become less rigid to enable staff, in subjects where teachers were scarce, to be recruited or retained by higher rewards than in others where mobility was low and availability high.

Fifth, in the university sector, resources for research were to be redirected on the basis of evaluations of the quality of research, with increasingly large sums going to those universities achieving the highest research "ratings". In short, there was a considerable and consistent pressure on the universities, in particular, and to a lesser extent in the Polytechnics, to change and to respond more to the "marketplace".

The effect of these policy initiatives has been mixed. Much change has occurred - more than is normally seen discussed in the public media. Universities are probably more "efficient"; if there was any waste of resources a decade ago, there is certainly none now. "Productivity" is higher: across higher education as a whole, more students are taught by fewer staff. Research output has increased. New modes of teaching have been introduced. There is more choice of courses. At the same time, there has been a price to pay. In particular, the time needed to enable the scholar to think and to write has been reduced. A1 though very difficult to measure empirically, it is likely that - at least in this respect — quality has suffered.

\section{The Response of the Law Schools}

The response of the Law Schools ${ }^{10}$ to these pressures might have been very negative. In fact it has been extremely positive. Well before the financial crisis of the 1980s began to bite, Law Schools had begun to change in a whole variety of ways. For example:

- The curriculum was being broadened. New subjects were introduced to reflect the development of new areas of law. ${ }^{11}$

- The scope of legal education was widened. There was an increasing desire to set the study of particular subjects into a wider social, economic and political context. ${ }^{12}$ The "Blackletter" 
tradition was challenged and supplemented by a new contextual approach.

- New models of legal education were introduced. Students could mix periods of study with periods in law offices. ${ }^{13}$ Some Law Schools offered "clinical" programmes, on the American model. ${ }^{14}$

- More generally the place of the Law School in the University system had become much more secure. ${ }^{15}$

In the 1980s these trends continued. As the Law Schools were in the fortunate position of being able to attract overseas students, this provided some financial cushion which to a degree protected Law Schools from the worst effects of the cuts. In the 1980s, therefore, further developments occurred:

- There was a considerable expansion of taught courses at the postgraduate (Masters) level.

- Many Law Schools made a considerable investment in the provision of continuing legal education, in particular for the solicitor's branch of the profession. This occurred at a time when the practising branches of the legal profession both came to realise that, in order to sustain and develop public confidence in lawyers and the services they provided, it was essential to demonstrate that their members were keeping up with developments in the law as was commonplace with the other learned professions.

- With the approach of the single European Market at the start of 1993, there was a sharp increase in courses affording opportunities for English students to study abroad in Europe (with reciprocal arrangements bringing Continental Europeans to England).

- Less widespread, but nonetheless of value, has been the introduction of computer technology and the opportunities for teaching students new research techniques, computer assisted learning, and the like. ${ }^{16}$

- Underpinning these developments was an almost inexorable rise in the popularity of law courses. Application levels for admission to law programmes soared. This was partly the result of the two branches of the legal profession deciding, in effect, that they would move to become all-graduate professions. ${ }^{17}$ It also resulted from the great expansion in the practising branches 
of the legal profession and the increasing salary levels that were reported as being achieved in legal practice.

- At the same time, legal academics became increasingly involved in activities outside the academy. They undertook consultancy; they advised government departments and governmental agencies; they were appointed to a number of judicial (typically tribunal) posts; they were involved in the work of law reform agencies; they undertook policy-related research. ${ }^{18}$

Two specific — and related — developments did, however, begin to cause unease within Law Schools. First, the fact - already noted — that the 1980s was a time of enormous expansion, not only in the provision of legal services but also the levels of reward that those who provided them were able to command, was having an impact on recruitment into the academic branch. While it is hard to demonstrate that the quality of young person becoming law teachers has fallen, the numbers interested in a life of teaching and scholarship do seem to have dropped. There are now rather less applicants for posts than was the case a decade ago. Secondly, as the larger legal practices become ever more committed to the professional development and continuing legal education of their staff, increasing numbers of offers (that it was hard, if not impossible, to refuse) were being made to legal academics to tempt them to move into firms, to organise training programmes and other "knowhow" services. ${ }^{19}$

Thus, experienced academics were being lured away from the academy; and their replacements were, perhaps, not quite so well qualified.

\section{The Challenge of the 1990s}

The current position is then, that while much energy and innovation has resulted in the legal academy in England becoming increasingly productive, there are problems ahead which those who now have the responsibility for offering leadership to the academic branch of the legal profession must come to terms with and seek to resolve. The challenges which we face are, in my view, as follows:

Expansion. Law Schools, particularly the larger better funded ones, do have an academic need to expand, not without limit, but in a measured way. ${ }^{20}$ The reason for this is that the legal context within which we live becomes seemingly ever more complex. It 
must be the claim of the leaders of the academic community that they are at the "cutting edge" of their discipline. (This "cutting edge" can of course exist either in the teaching or the research functions of the legal scholar. Academics do, however, need to be conscious of this objective lest, under the pressures which are now imposed upon them, they stop thinking about this. If this happens, they will fail to have the forward looking approach that should characterise the lively scholarly community. They will fail to be taking the risks to develop new areas of research, or new modes of teaching that they ought to be looking at.) The "core curriculum" does not change, but new areas of law constantly open up which should be the focus of scholarly attention. For these reasons, inter alia, we do need to find more scholars able to move into new areas of teaching and research.

Resources. The policies of the major political parties give no suggestion that there will be any significant increase in resources, at least, not for the Universities. While overseas students obviously have a valuable role to play in law departments - and more generally can provide a means for helping to sustain the vitality of the common law - too great a financial dependence on them is perhaps unwise. The home countries of such students are - quite rightly - constantly seeking ways to reduce the outflow of resource that studying abroad represents. Thus the Law Schools do need to explore alternative sources of additional income.

Teaching Quality. Complementing the surveys and assessments of research quality, it is inevitable and proper that arrangements for assessing the quality of teaching must be put in place. The first steps towards the Universities' Academic Audit have now been taken. The Law Schools need urgently to think about how to respond to this, in order to develop the audit process in such a way as will demonstrate the good quality of the teaching that is offered. ${ }^{21}$

The Collapse of the Binary Line. It is equally inevitable that the sharp distinction between Universities and Polytechnics, that has existed for the last twenty years or so, will disappear. Polytechnics will shortly be able to retitle themselves as Universities. In principle, this is strongly to be welcomed. This very fact does, however, create its own challenges. Amplifying a point already mentioned, it is unlikely that the Government will 
provide additional levels of funding to allow all institutions of higher education to undertake research in the way universities have until now. Thus it is likely that rather sharp distinctions will have to be drawn between "research" universities and "teaching" universities, or perhaps some status in between. If so, how are decisions to be reached? Once decided, will decisions be changeable? The implications of such changes are likely to be difficult and painful.

The Status of the Academic Lawyer. But perhaps the greatest challenge facing the legal academy - which in effect brings together the more specific matters set out in the preceding paragraphs - is to define and develop a recognition of the appropriate status of the academic lawyer in English legal culture. It is in this context that the academic must look beyond the narrow world of the academy and instead seek both to understand and to influence the wider legal world beyond. This will involve the development of an increasingly constructive relationship partnership, even - between the worlds of the scholar and the practitioner. It is to this specific theme that I now turn.

\section{PART TWO - ACADEMIC LAWYERS AND PRIVATE PRACTICE}

Academic lawyers in England have, for a long time, had frankly rather an awkward even limited relationship with legal practitioners. As long ago as 1846, a Parliamentary Select Committee on Legal Education observed that in England there were:

... few examples of that important class of thinkers who, in other countries, standing on the summit of the profession and disengaged from the turmoil and labour of its daily technical duties, have to keep the [legal] profession up to the intellectual height to which it should be its proudest boast to aspire.. $.2^{22}$

One hundred and twenty years later, Professors Abel-Smith and Stevens concluded in Lawyers and the Courts, that: University Law Faculties ... lacked prestige ... with the [legal] profession. ${ }^{23}$

Twenty years on, and similar claims were still being made: for example, Atiyah:

In the English legal system the scholar as teacher is a person with a 
decidedly inferior status... ${ }^{24}$

And Wilson:

... this sense of difference of status has been reinforced in the past by the difficulty in identifying any obvious role for the legal scholar other than teaching future practitioners ... [There] is only a limited informal network of contacts between legal scholars in general and those who bear the main responsibility for administering the law. ${ }^{25}$

Such statements, if justified, demonstrate the extent of the challenge that faces the academic legal community.

The impression I have - and it is only an impression - is that while twenty-five years ago (when coincidentally I was first offered an academic appointment) the conclusion at which Abel-Smith and Stevens arrived was probably more or less justified, the more recent statements are less descriptive of a reality that I know. Below, I set out ways in which I suggest that both the influence of the legal academic — in both teaching and research — is stronger than suggested by Atiyah, and the networks are more formal and stronger than suggested by Wilson.

\section{The Definition of "Legal Practice"}

First though, we must be clear about what is meant by the world of legal practice. For the purpose of this argument, 'legal practice" comprises what I have described elsewhere ${ }^{26}$ as two conceptually distinct components: a "private practice" component, which involves the day-to-day operation and administration of the law and the legal system; and a "public policy" component, which focuses on the development, through public policy initiatives, of the law. Thus while the former will also include those creative but rather unpredictable developments in our jurisprudence that arise intermittently - from litigation in the courts, the latter embraces all those developments in the law which derive from legislation enacted by Parliament, together with policy initiatives started within Government. A definition of "legal practice" which includes the whole range of activities which lead towards the development of a legal culture is of considerable significance when trying to understand and develop the relationship between the academic lawyer and "legal practice". 


\section{Teaching}

\section{The "Academic" Stage}

Twenty-five years ago, it was very common for lawyers to qualify - either as barristers or solicitors - without obtaining a law degree, or indeed, any degree at all. This situation began to change rapidly after 1971. In that year the Report of the Ormrod Committee $^{27}$ concluded that all lawyers should start the process of obtaining professional qualifications by first completing an "academic" stage of education. In order that students, by completing a law degree, were able to obtain exemption from the first part of the subsequent professional examinations it was necessary that students should study six "core" subjects. ${ }^{28}$ The syllabuses for these subjects were, initially, prescribed in some detail. In practice, however, the teaching institutions found that they had considerable flexibility in the way they taught and assessed these courses and in the content. In the last twelve months, this more relaxed approach was formally recognised. A joint working party - representing the teaching institutions, the Bar and the Law Society - replaced the old syllabi with much briefer "outlines" of topics that should be covered (and which in reality are covered). In short, the practising branch of the profession had accepted that the teaching institutions could be relied on to put suitable courses together, so that any attempt by them to intervene was unnecessary. Furthermore, under the Courts and Legal Services Act 1990 - which, infer alia establishes a new Advisory Committee on Legal Education and Conduct - the so-called "academic" stage has, in fact, received statutory recognition. ${ }^{29}$

The fact that, effectively, all new recruits to legal practice now have degrees, a majority of them law degrees, is important in the context of this discussion. For whereas twenty-five years ago many leaders of the profession knew next to nothing of the universities (and, doubtless, cared less), the present generation is aware of what the legal academy has to offer. This is a trend that will continue.

\section{Continuing Legal Education}

A second development, already noted, which brings legal academics and legal practitioners into closer contact results from a 
new commitment to continuing legal education. The Law Society has embarked on a policy which, by 1995 will require all solicitors who entered the profession after 1965 to undergo continuing legal education each year. Within the last twelve months, the Bar has also taken steps to introduce compulsory continuing legal education.

Although much of this is done "in-house" by larger firms, and much is also done by commercial training companies, the universities and polytechnics have played a very substantial part in this development. This has the particular value of bringing academics and practitioners together to discuss developments in specific areas of law. In addition to short “updating” programmes, continuing legal education is also becoming linked with two further developments: specialisation and retraining.

- Specialisation is, increasingly, a feature of modern practice. While many more senior lawyers deplore this, particularly when specialisation starts at a very young age, the way particularly the larger firms currently organise themselves does require this. In addition, there are public interest arguments that those who claim a particular specialism should be able to demonstrate an adequate grasp of that specialism. For this reason, numbers of practitioners do now seek further qualifications in new subject areas - often in the form of modules from taught Master's programmes.

- Retraining becomes urgent in times of economic downturn when specialised skills are no longer commercially viable. Again the academic institutions have a potentially important role to play in this as well. In addition there is also a number of special programmes, eg to encourage women returners.

Related to this, important initiatives have also occurred in the area of judicial training. Ten years ago this would have been limited, almost exclusively, to instruction on sentencing for magistrates. The former assumption that judges knew everything has been replaced by a rather more open-minded approach. Now increasingly sophisticated programmes are being organised for the judiciary — at all levels — in which there is a not inconsiderable input from academic 1awyers. ${ }^{30}$ 


\section{The Vocational Stage of Legal Education}

A third development relates to the vocational stage of legal education, which follows from the completion of the academic stage. Here, the two branches of the practising profession have retained much greater control. The Bar runs courses at the Inns of Court School of Law. The Law Society runs its vocational stage through the College of Law, in association with a number of polytechnics. Within the last twelve months, however, significant changes have been introduced.

The Bar's final course was substantially revised, in 1990, to include a much larger element of instruction on the skills needed to become an advocate. (The content and structure was heavily influenced by courses offered in other parts of the common law world.) The current view at the Bar is that the course has to be run in a single location in London, since a key component of the course is instruction and assessment by practitioners in the arts of advocacy and court procedure.

This is causing two problems:

- Space at the Inns of Court School of Law is finite. Thus numbers coming on to the course have to be strictly limited. ${ }^{31}$ Those who are not intending to practice at the English Bar are not permitted to take the course; this includes very many overseas students.

- The syllabus for the Bar course taken by those who do not intend (or will not be able) to practice in England remains the old, unreformed one. This is causing increasing resentment since, it is argued, the students are offered a second-class programme.

It is very likely that the syllabus for the latter category will shortly be brought into line with the new ICSL course. But it will have to be taught elsewhere. I predict that at least one of the law teaching institutions will become authorised to offer this new programme. The Law Society have been bolder. The Law Society Final course was last reformed in 1979. It then had as its objective, the aim of introducing students to practical skills as well as areas of substantive law. However, the course was taught in a number of different locations. A particular feature of the way the course was organised was that there was a single, centrally-set examination, which all students had to take. This had the effect of making both the teaching institutions and their students concentrate almost entirely on learning the rules 
essential to pass the written examination. Little more than lip service was given to the skills element.

To overcome this, the Law Society has in July 1991, passed proposals for a new course to be introduced in 1993 which will address the problems associated with the existing course. In particular, while each authorised teaching institution will be required to provide a course that meets objectives set out in a detailed set of written standards, the modes of teaching and assessment will be for each teaching institution to determine. Common standards will be achieved by detailed monitoring of the institutions through a new Legal Practice Course Board.

The significance of these moves can hardly be overstated. Since the Law Society has come to accept that in general terms, the teaching institutions can be relied upon to offer appropriate vocational courses as well as the academic stage and the continuing stage, $)^{32}$ the teaching institutions now have the opportunity to develop and experiment with their modes of vocational instruction in a way that has not hitherto been possible.

In my view it is essential that at least some university law departments play a part in this development, as well as the College of Law and the polytechnics. Many law teachers are likely to resist this argument, claiming that the primary justification for the teaching of law - particularly in the universities - is the intellectual discipline that is associated with the study of law. A broader vision, however, would embrace both the liberal educational values associated with this point of view and a wider concern that education - in its broadest sense - should be associated with the formation of individual professional identities. If this wider view becomes accepted, this would do much to widen the influence of legal academics in the English legal system and legal profession.

\section{Research and Scholarship}

In addition to teaching, legal academics also have a commitment to research and scholarship. It seems clear on the basis of my 1982 survey that the product of this research and scholarship is, in fact, applied in the world of legal practice (as defined above) to a very substantial degree. ${ }^{33}$ Although a follow-up study has not yet proved possible, it is reasonable to assume that the involvement 
of legal academics in legal practice is now even greater than it was then. The survey showed that legal academics were engaged in a wide variety of activities in a wide range of contexts:

- part-time practice (usually related to areas of research interest);

- part-time legal advice work; commercial consultancy;

- part-time judicial (including tribunal) work; membership of governmental bodies (both standing committees and ad hoc bodies established for particular purposes);

- membership of international organisations;

- membership of political groups;

- membership of private pressure groups;

- membership of professional bodies (both legal and others);

- advisers/consultants of foreign governments;

- arbitration;

- law reform bodies. ${ }^{34}$

And it should not be forgotten, of course, that very many practitioners use the product of the legal academics' research and scholarship, which is published in texts, books and articles, and other legal commentaries.

No "audit" of the extent and nature of any influence from the work of legal academics has been undertaken. But it is not hard to think of issues which have been taken up and debated in the academic literature which have influenced thinking both in practice (eg judicial review) or in policy making (eg models of legal service delivery). Furthermore, the academic community is now more involved in research projects which are likely to result in changes to the law, legal process or the legal profession than was the case 10-15 years ago.

Undoubtedly there are dangers involved in the academic community becoming too closely locked into policy-driven research programmes, particularly if that is the only kind of research for which resources are available. At the same time, however, these developments would not have occurred if those outside the legal academy had not found the work of legal academics to be of value.

\section{Investment in the Academy}

The value of a strong academic base for legal practice is also acknowledged by the increasing investment or sponsorship of 
academic activity by private practice. This can take a variety of forms:

- firms may sponsor a post in a particular area;

- they may “top-up” a lectureship to create a chair;

- they may sponsor research posts;

- they may assist with the funding of library holdings;

- less frequently, they may assist with the finance of capital projects.

Where individual firms engage in such sponsorship, strings usually come attached. The department/faculty concerned may have to provide teaching to the firm, or other contributions to "knowhow". The firm may seek to acquire access to students, eg by the delivery of lectures.

Another recent initiative has been the creation of the City Solicitors' Educational Trust, funded by the large firms in the City of London, who have made a number of grants to law departments to assist with "core" undergraduate teaching. These resources are freer, in that they do not impose any direct reciprocal obligation on the academic departments to provide services to specific firms. In addition, the sponsorship of students by firms is now very common - particularly at the vocational stage of training.

In all these respects, Government policy noted above - to get "industry" investing more in higher education — is proving increasingly successful, and as a trend is likely to continue.

\section{CONCLUSIONS}

The thesis of this paper is that academic lawyers in England are moving closer towards having the kind of influence in the development of law in England that the Select Committee of 1846 argued was desirable. The downbeat conclusions expressed by Abel-Smith and Stevens are no longer valid. The view of Atiyah and Wilson seem based on too limited an analysis of what the academic legal community is actually doing.

In making this argument it is important not to overstate the case. First, the day-today administration of the law is clearly in the hands of the practitioner. Legal academics have some role to play through advisory work or consultancy or part-time judicial work, but it is a limited involvement. Indeed in some areas of practice, especially rapidly developing parts of commercial law or tax law, academics 
appear to play almost no part at all. Secondly, many areas of the law are developed through the creativity and imagination of solicitors and barristers in practice. The judiciary, too, are able to make significant developments. ${ }^{35}$ Nonetheless, given the changing nature of the law - much greater emphasis on statute, less on the role of the common law - means that more often than not developments occur in Parliament and Government, rather than the courts, where legal academics can have a more significant voice. Thirdly, the work of many legal academics is, in any event, not directed towards the concerns of legal practice, however broadly defined. Indeed, the academic freedom of scholars to undertake work which they have defined for themselves rather than have had defined for them is a precious one that must be strongly defended. It is they who will help to remind us that our law and legal system is not simply about the operation of markets, but does embody fundamental societal values. While the case for the academics must not be overstated, equally it must not be understated. Historically the relationship between the legal academic and the legal practitioner in England has been too unequal. The evidence presented here indicates that the current position is that legal academics have a more important role to play in the development of law in England than is often appreciated. The legal academic community as a whole, should recognise this and in an appropriate manner, should assert that it has a contribution to make to the development of law in England that while different from that of the practitioner, is nonetheless of significance.

It must also be recognised that the interests of the practising branches and the academic branch will by no means always coincide. For example, while institutions of higher education are being encouraged to give access to ever more students, the professions may not be able to absorb all those graduates who might wish to practise law. Law schools may need to think very carefully about possible alternative careers for their students outside of the legal profession.

There will be some academics who will argue that the scholar should have no involvement with the world of practice. I think there are at least two strong reasons for rejecting this view. First, there is no contradiction between the highest standards of legal scholarship and practical utility. Being interested in practical issues 
does not compromise academic integrity. To the contrary: in many areas of law - especially those dominated by statute and regulation - an adequate understanding of the law can only be achieved by an understanding of how the law operates in practice. Secondly, other disciplines in the academic community have benefitted from developing links between scholars and practitioners: the medical disciplines, the engineering disciplines, education are all examples of disciplines enhanced by a strong relationship between the world of the academy and the world of practice.

It is the responsibility of academic communities, in general, to give leadership to the development of their discipline. In England, the legal academy for too long - and with notable and honourable exceptions - failed to demonstrate to the full its ability to give leadership to the development of the discipline of the law. The position has changed and is changing rapidly. We need to acknowledge this and indeed, refine our theories of legal education and scholarship to take account of this.

The main challenge now facing legal academics in England in the 1990s is to encourage them to consolidate the changes of attitude and practice that have occurred in the last 10-20 years, and in partnership with the practising branches of the legal profession, to explore ways of enhancing the contribution they make to the development of the law, legal services and the legal system. Such a partnership, in which the legal academic retains a clear identity but on a basis of equality, is necessary to encourage bright young scholars to come into the academic branch. We need to think of the nature of the career we can offer, as much as the practising branch. Indeed both branches of the legal profession should think more seriously about devising mechanisms to enable much easier transfers from the academic to the practical world, and vice versa, than has been the case so far. By combining our strengths, it may be possible to exercise the kind of influence necessary to secure an adequate funding base, and thereby begin to resolve some of the very real difficulties sketched out in the earlier parts of this paper.

* Faculty of Law, University of Bristol. This paper is the revised text of a Paper presented to the Australasian Law Teachers Association 46th Annual Meeting, Perth, Western Australia on 12 July 1991. I am grateful to participants at the Conference for their comments; also to Professor Avrom Sherr, Liverpool University, and to Phi1 Jones, Polytechnic of, Central London for helpful 
suggestions and the correction of a number of errors.

(C) 1992. (1992) 3 Legal Educ Rev 75.

1 I am aware that it is perfectly plausible to argue that law teaching is but one aspect of the practice of the law; for the purpose of the argument in this paper, however, I think it helpful to retain the distinction.

2 Scotland and Northern Ireland are quite different.

3 Committee on Higher Education, Higher Education, (Cmnd 2154, 1963).

4 See for example M Kogan, The Attack on Higher Education (London: Kogan Page, 1983).

5 There was a considerable programme of "voluntary" redundancies and early retirements which were, in fad, quite generously funded by the Government.

6 See Higher Education: A New Framework (Cm 1541, London, 1991) esp Annex 2.

7 Right from 1981 the Universities and Polytechnics became effectively obliged to do this in the context of the fees charged to students from overseas.

8 The Polytechnic sector was always more willing to respond to these pressures; indeed, in order to be attractive to potential students, it often took the lead in developing courses to enable vocational goals to be achieved.

9 Report on the Standing Committee for Efficiency Studies in Universities (Chair: Sir Alex Jarratt) (London: Committee of Vice-Chancellors and Principals, 1985).

In this section, I shall focus primarily on the University Law Schools.

11 Most law schools now offer subjects (eg Intellectual Property Law, Banking Law, Environmental Law, Consumer Protection Law, Women and the Law) that were not available $10-15$ years ago.

12 These developments were encouraged by the foundation of new Law Schools in the 1960s such as those at Warwick and Kent Universities.

13 For example, the programmes offered by Brunel University or Nottingham Polytechnic.

14 The best review is in the (unpublished) Ph.D thesis by Julie MacFarlane, currently working at the City Polytechnic of Hong Kong.

15 See W Twining, "Goodbye to Lewis Eliot. The Academic Lawyer as Scholar" (1980) 15 J Soc Public Teachers of Law pp 2-19.

16 These developments have been encouraged by BILETA — the British and Irish Legal Education Technology Association — based at Warwick University.

17 See RL Abel, The Legal Profession in England and Wales, (Oxford: Blackwell, 1988).

18 See M Partington, Academic Lawyers and 'Legal Practice' in Britain (1988) 15 J of Law \& Soc 374.

19 The Legal Education and Training Group now has over 100 members, a significant number of whom have been appointed from University or Polytechnic Law Schools.

20 Changes in the way in which Universities are funded will also lead to financial pressures to expand that are not necessarily desirable on academic grounds. There has been a marked shift in funding from the Funding Councils to the fees brought to the University (and Polytechic) by students: see Cm 1541 supra note 6 Annex 1.

21 See Cm 1541 supra note 6 at Ch 5.

22 Quoted by B Abel-Smith \& R Stevens, Lawyers and the Courts (London: Heineman 1967) at 68-69.

23 Id.

24 PS Atiyah, Pragmatism and Theory in English Law (London: Stevens, 1987) at 35. 
GP Wilson, “English Legal Scholarship” (1987) 50 Mod L Rev 818 at 842.

26 Partington supra note 18.

27 Report of the Committee on Legal Education Cmnd 4594, (London: HMSO, 1971).

28 Land Law, Constitutional and Administrative Law, Trusts, Criminal Law, Contract Law and Tort Law.

29 See for example Courts and Legal Services Act 1990, Sched 2 paras 2 \& 3.

30 See Judicial Studies Board, Report for 1983-7 (London: HMSO, 1988).

31 It is arguable that a consequence of this practice is that present rules relating to entrance to the Bar are anti-competitive, contrary to the philosophy enshrined in the Courts and Legal Services Act, 1990.

32 The new Legal Practice Course will be supplemented by a Professional Skills Course - taken by trainee solicitors during the period of their traineeship which will remain under the control of the Law Society.

33 See Partington, supra note 18.

34 Particularly the Law Commission, where those "learned in the lay" receive statutory recognition: Law Commission Act 1965.

35 There has been no attempt to assess the extent to which practitioners and the judiciary have, in fact, been influenced by their academic mentors, though see $\mathrm{R}$ Goff, The Search for Principle (1983) 69 Proceedings of the British Academy 169. 